\title{
MINERAL RESOURCE POTENTIAL OF THE DOMELAND WILDERNESS AND CONTIGUOUS ROADLESS AREAS, KERN AND TULARE COUNTIES, CALIFORNIA
}

\section{SUMMARY REPORT}

\author{
By
}

\section{J. R. Bergquist, R. C. Jachens, and W. R. Miller}

U.S. Geological Survey

and

\section{A. M. Leszcykowski and J. M. Spear}

U.S. Bureau of Mines

\section{STUDIES RELATED TO WILDERNESS}

Under the provisions of the Wilderness Act (Public Law 88-577, September 3, 1964) and related acts, the U.S. Geological Survey and the U.S. Bureau of Mines have been conducting mineral surveys of wilderness and primitive areas. Areas officially designated as "wilderness," "wild," or "canoe" when the act was passed were incorporated into the National Wilderness Preservation System, and some of them are presently being studied. The act provided that areas under consideration for wilderness designation should be studied for suitability for incorporation into the Wilderness System. The mineral surveys constitute one aspect of the suitability studies. The act directs that the results of such surveys are to be made available to the public and be submitted to the President and the Congress. This report discusses the results of a mineral survey of the Domeland Wilderness, the Domeland Addition Roadless Area, and the Woodpecker Roadless Area, Sequoia National Forest, Kern and Tulare Counties, California. The Domeland Wilderness (NF019) was established by Public Law 88-577, September 3, 1964. The Domeland Addition (02507) and Woodpecker (02506) Roadless Areas were classified as further planning areas during the Second Roadless Area Review and Evaluation (RARE II) by the U.S. Forest Service, January 1979.

\section{SUMMARY}

The Domeland Wilderness and the contiguous Domeland Addition and Woodpecker Roadless Areas are situated along the crest of the southern Sierra Nevada. The wilderness area includes the Domeland, a unique $35-\mathrm{mi}^{2}$ area of sparsely vegetated large rounded domes of white granitic rock.

The only identified resource is in the Woodpecker Roadless Area, where older Quaternary gravel in Rockhouse Basin contains small irregular low-grade deposits of placer gold.

A low potential exists for the occurrence of very small deposits of uranium in fractures in granitic rocks west of the South Fork of the Kern River in the Domeland Wilderness. The probable small size of the potential uranium deposits, as well as the extremely rugged terrain of the area, will likely preclude development.

A low potential exists for a porphyry molybdenum deposit at the south end of the Domeland Wilderness. This evaluation is based solely on geochemical data from stream sediment and spring waters; there is no other corroborating geologic evidence.

A low potential exists in the study area for very small deposits of tungsten, copper-lead-zinc, tin, silver, and molybdenum, as indicated by geochemical data. These deposits are likely to occur as contact-type mineralization in tactite near contacts between older metamorphic rocks and younger intrusive granitic rocks, or as hydrothermal vein-type mineralization. Although the geochemical anomalies may be related to mineralization, their distribution and relatively small sizes probably do not indicate significant undiscovered mineral deposits.

The Domeland Wilderness and contiguous roadless areas have no indications of potential for coal, oil and gas, or geothermal energy.

\section{INTRODUCTION}

To evaluate the mineral resource potential of the Domeland Wilderness and contiguous roadless areas, the U.S. Geological Survey conducted geologic mapping (Bergquist and Nitkiewicz, 1982), geochemical studies (Motooka and others, 1980; Miller and McHugh, 1983; Miller and others, 1983a, b), and geophysical surveys (U.S. Geological Survey, 1979; Jachens, 1983) in 1979 and 1980 . The U.S. Bureau of Mines surveyed, sampled, and evaluated known mines, prospects and mineralized zones during 1979. Information on mines and prospects was obtained from the U.S. Bureau of Mines, the U.S. Geological Survey, and the California Division of Mines and Geology. U.S. Forest Service records and the courthouse records of Kern and Tulare Counties were searched for information on mining claims within the study area. This report presents an evaluation of mineral resource potential determined from field studies and laboratory analyses of samples.

\section{Location and geographic setting}

The Domeland and contiguous roadless areas are in Sequoia National Forest, on the crest of the Sierra Nevada near the south end of the range (fig. 1). The Domeland Wilderness includes 62,561 acres, the Domeland Addition Roadless Area 3,100 acres, and the Woodpecker Roadless Area 44,000 acres, for a combined total of 109,661 acres. The town of Kernville is $10 \mathrm{mi}$ west of the wilderness, at the north end of Isabella Lake; Bakersfield is $45 \mathrm{mi}$ southwest. The south end of the wilderness is accessible by roads leading from State Highway 178. Access from the west, north, and east is from State, county, and U.S. Forest Service roads that in places parallel the boundary of the Woodpecker Roadless Area.

The South Fork of the Kern River flows southward through both the Woodpecker Roadless Area and the wilderness, then westward through South Fork Valley into 
Isabella Lake. The South Fork has cut a steep and rugged Vshaped canyon, as deep as $3,000 \mathrm{ft}$, between Rockhouse Basin and South Fork Valley in the wilderness. West of Rockhouse Basin is the Domeland, a unique area of approximately 35 $\mathrm{mi}^{2}$, characterized by numerous hemispheric to elongate northeast-trending granitic exfoliation domes. The domes vary in size from a few hundred feet in diameter and 50 to $100 \mathrm{ft}$ high, to approximately $5 \mathrm{mi}$ long, 1 to $2 \mathrm{mi}$ wide, and more than $2,000 \mathrm{ft}$ high. The domes are relatively barren of vegetation except for brush and trees growing in crevices.

Elevations in the study area range from about $3,000 \mathrm{ft}$ near the South Fork Valley, in the southern part of the wilderness, to $9,977 \mathrm{ft}$ at Sirretta Peak, near the west edge of the Woodpecker Roadless Area. Lower elevations support desert flora, including cacti and Joshua trees. The higher elevations have open coniferous forests of red fir, white fir, yellow pine, and Jeffrey pine. The Domeland Wilderness and the Woodpecker Roadless Area are crossed by numerous hiking trails, including the Pacific Crest Trail.

Previous geologic maps by Miller (1931) and Miller and Webb (1940) included the Domeland Wilderness, the Domeland Addition Roadless Area, and part of the Woodpecker Roadless Area.

\section{Regional mining activity}

No mineral production has been recorded from the wilderness or roadless areas. The closest mining district, the Cove district, is near Kernville, approximately $8 \mathrm{mi}$ west of the south end of the Domeland Wilderness. Areas along the Kern River near the Cove district were prospected and mined for placer gold beginning in 1851 , but by 1855 most mining ceased because of low placer gold values (Troxel and Morton, 1962 , p. 27). Gold-quartz veins were discovered in the Cove district in 1860. A total of $\$ 5$ to $\$ 8$ million in gold was produced from the d'strict before 1883; between 1936 and 1943 , when the mines were closed by Government order, more than $\$ 1$ million in gold and minor amounts of silver, lead, and copper were produced (Troxel and Morton, 1962, p. 27-29).

The Kern River uranium area is $17 \mathrm{mi}$ southwest of the south end of the wilderness. Uranium deposits discovered there in 1954 occur locally along fractures in the granitic rocks. Only about 189 tons of ore were reported to have been shipped; the richest shipment was 46 tons of ore that averaged 0.62 weight percent uranium oxide $\left(\mathrm{U}_{3} \mathrm{O}_{8}\right)$ (MacKevett, 1960, p. 205).

Several tungsten prospects are located outside the Woodpecker Roadless Area, approximately $1.5 \mathrm{mi}$ east of Rockhouse Basin in sec. 30, T. 23 S., R. 36 E. A caved shaft and headframe at one prospect are visible from the road to Rockhouse Basin. At another prospect, an adit, compressor shed, and toolhouse are still standing. Some samples from the adit contained significant amounts of tungsten trioxide $\left(\mathrm{WO}_{3}\right)$.

\section{GEOLOGIC SETTING}

Metamorphic and plutonic rocks typical of the Sierra Nevada underlie the study area. Pre-Middle Jurassic metasedimentary and metavolcanic rocks were intruded by a succession of younger Mesozoic plutons of varying composition. The metamorphic rocks crop out as roof pendants and septa with steeply dipping beds that trend north-northwest and commonly erode to "tombstone" rocks. The metasedimentary rocks consist mostly of interbedded quartzite, mica schist, phyllite, marble, and subordinate amounts of slate and metavolcanic rock. The metasedimentary rocks may, in part, be lateral equivalents of the Paleozoic sedimentary rocks exposed east of the Sierra Nevada, or they may correlate with Mesozoic metamorphic roof pendants to the north and south. In places, the marble is highly siliceous and has locally been replaced almost entirely by wollastonite. Zones of quartz-epidote skarn occur in the northwest part of the Woodpecker Roadless Area between Trout Creek and Machine Creek. The marble and skarn are of particular interest because elsewhere they are host rocks for tungsten and other mineral deposits.

There are three distinguishable intrusive bodies in the study area and they are progressively more felsic with decreasing age. The Summit Gabbro of Miller and Webb (1940), the oldest intrusive unit, is the least extensively exposed unit in the study area. The gabbro commonly is closely associated with, and may be an early border phase of, the younger Sacatar Quartz Diorite of Miller and Webb (1940), a mesocratic hornblende tonalite dated at about 145.4 m.y. by R.M. Tosdal (in Bergquist and Nitkiewicz, 1982). The youngest and most extensive intrusive unit in the area is the Isabella Granodiorite of Miller (1931), dated at 81.1 m.y. by R.M. Tosdal (in Bergquist and Nitkiewicz, 1982). The Isabella Granodiorite ranges compositionally from granite to granodiorite but is predominantly a granite characterized by large phenocrysts of potassium feldspar. Other rock units similar to the porphyritic Isabella Granodiorite have been identified along parts of a $160 \mathrm{mi}-$ long segment of the crest of the Sierra Nevada; these units were designated "Cathedral Peak-type plutons" by Evernden and Kistler (1970).

Overlying the metamorphic and plutonic units are erosional remnants of late Tertiary volcanic flows of olivine basalt and, less commonly, andesite.

Alkali olivine basalt from Black Mountain yielded a whole-rock age of 12.3 m.y. (Miocene) (R. M. Tosdal in Bergquist and Nitkiewicz, 1982). Other samples of alkali olivine basalt from the Kern volcanic field on the Kern Plateau yielded ages of $3.6 \mathrm{~m} . \mathrm{y}$. (Pliocene) and younger (Moore and Dodge, 1980). This wide variation in ages from the same region suggests two periods of volcanism. Moore and Dodge (1980) reported a similar variation in the ages of basalt flows in the San Joaquin-Kings volcanic field on the west slope of the Sierra Nevada. There, the first period of volcanism occurred during the late Miocene (12-9 m.y.B.P.), and the second during the Pliocene (4.5-3 m.y. B.P.).

The study area is crisscrossed with lineaments, most of which are fractures or faults with very little descernible displacement. Some of the more conspicuous lineaments are faults, defined in places by mineralized zones, scarps, springs, drag flexures, and offset lithologies. Most of these lineaments are within monolithologic igneous bodies, and so fault displacements are difficult to discern. A dominant northeast-trending set and a subordinate northwest-trending set of joints were instrumental in the control of the form of the domes. The Kern Canyon fault is a major north-southtrending regional structure about $5 \mathrm{mi}$ west of the wilderness boundary.

\section{GEOCHEMISTRY}

A geochemical survey of the Domeland Wilderness and the Woodpecker and Domeland Addition Roadless Areas was conducted by the U.S. Geological Survey in summer 1979 to provide a geochemical framework with which to evaluate the mineral resource potential of the area. Samples of stream sediment and water were analyzed. The stream-sediment samples were panned concentrates, and the magnetic and nonmagnetic fractions were analyzed separately. Descriptions of the sampling and analytical methods were given by Miller and McHugh (1983) and Miller and others $(1983 \mathrm{a}, \mathrm{b})$. Numerous anomalies were discovered, but only two are significant. The first (area 2, fig. 2) is a uranium anomaly in both water and stream sediment in the Domeland Wilderness west of the South Fork of the Kern River. The second (area 3, fig. 2) consists of anomalous concentrations of elements that are commonly found in association with porphyry molybdenum mineralization, in the southern part of the wilderness south of Pilot Knob.

\section{Areas of geochemical anomalies}

South Fork of the Kern River anomaly (area 2, fig. 2)

Anomalously high concentrations of uranium and anomalously low thorium/uranium ratios occur in stream sediment on the west side of the South Fork of the Kern River in the Domeland Wilderness. The nonmagnetic fraction of panned concentrates also contains anomalous concentrations of bismuth, tungsten, and barium (Miller and 
others, 1983b); the magnetic fraction contains anomalous concentrations of copper, molybdenum, and zinc (Miller and others, 1983a). Stream waters contain anomalous concentrations of uranium, arsenic, fluorine, molybdenum, sulfate, and zinc (Miller and McHugh, 1983). These concentrations of elements and sulfate support the identification of the geochemical anomaly. The area in which the anomaly occurs is entirely within the Isabella Granodiorite. This suite of anomalous elements is probably associated with contact-type and (or) vein-type mineralization. The presence of high concentrations of uranium together with the low thorium/uranium ratio suggests that uraninite-bearing veins may occur in fractures in the granitic rocks in several tributary drainages west of the South Fork of the Kern River.

Pilot Knob anomaly (area 3, fig. 2)

At the south end of the Domeland Wilderness, in an area underlain by the Isabella Granodiorite, anomalous concentrations of elements were found in both stream sediment and water. The magnetic fractions of panned concentrates from 15 sample localities contain anomalous concentrations of lead and thorium, and some also contain anomalous concentrations of silver, barium, molybdenum, and tin (Miller and others, 1983a). Ten sites in the area show anomalous silver and lead in the nonmagnetic fraction, and some of these samples also contain anomalous concentrations of molybdenum and tin (Miller and others, 1983b). Five springs in this area, all of which flow from within the wilderness, contain anomalous concentrations of arsenic, fluorine, molybdenum, sulfate, and zinc (Miller and McHugh, 1983). The anomalous geochemical suite of elements in this area is likely associated with highly differentiated silica-rich plutonic rocks that possibly have porphyry molybdenum mineralization. However, the geochemical signatures are not sufficient to predict the subsurface existence of such a deposit.

\section{Sirretta Peak anomaly (area 4, fig. 2)}

Sirretta Peak is in the southwestern part of the Woodpecker Roadless Area. The nonmagnetic fraction of panned concentrates from drainages around Sirretta Peak contains anomalous concentrations of barium, bismuth, molybdenum, lead, tin, and tungsten (Miller and others, 1983b). Stream waters have low $\mathrm{pH}$ values (Miller and McHugh, 1983). The bedrock in the area consists predominantly of the Isabella Granodiorite and small remnants of metamorphic roof pendants. This geochemical suite indicates contact-type or, possibly, hydrothermal veintype mineralization.

Black Mountain anomaly (area 5 , fig. 2)

In the center of the wilderness, near Black Mountain, the magnetic fraction of panned concentrates contains anomalous concentrations of silver, copper, molybdenum, and zinc (Miller and others, 1983a); the nonmagnetic fraction contains anomalous concentrations of bismuth, copper, lead, and tin (Miller and other, 1983b). This geochemical suite of elements is probably related to contact metamorphism or to hydrothermal vein-type mineralization.

Rockhouse meadow anomaly (area 6, fig. 2)

In the Domeland, west of Rockhouse Meadow, the magnetic fraction of heavy-mineral concentrates from stream sediment contains anomalous concentrations of lead, tin, copper, molybdenum, barium, and zinc (Miller and others, 1983a). Stream waters contain copper, fluorine, molybdenum, uranium and zine (Miller and McHugh, 1983). This geochemical suite suggests the presence of contact-type or hydrothermal vein-type mineralization.

Anomaly on the east side of Rockhouse Basin (area 7, fig. 2)

The nonmagnetic fraction of heavy-mineral concentrates from areas east of Rockhouse Meadow and Rockhouse Basin contains anomalous concentrations of barium, molybdenum, lead, copper, and tungsten (Miller and others, 1983b). Stream waters contain anomalous concentrations of arsenic, fluorine, copper, molybdenum, sulfate, uranium, and zinc (Miller and McHugh, 1983). Stream sediment contains anomalous concentrations of uranium (Miller and others, 1983b). The area is underlain by metamorphic rocks of the Kernville Series of Miller (1931), the lsabella Granodiorite, and the Sacatar Quartz Diorite of Miller and Webb (1940). This suite of elements and sulfate is probably associated with contact-type or vein-type mineralization.

Pine Mountain anomaly (area 8, fig. 2)

Pine Mountain is in the northeastern part of the Woodpecker Roadless Area. The nonmagnetic fraction of heavy-mineral concentrates from stream-sediment samples on the east side of Pine Mountain contains anomalous concentrations of molybdenum, tin, tungsten, and lead (Miller and others, 1983b). Stream waters contain anomalous concentrations of copper, fluorine, molybdenum, sulfate, and zinc (Miller and McHugh, 1983). The bedrock in the area includes the Isabella Granodiorite, the Sacatar Quartz Diorite, and metamorphic rocks of the Kernville Series. This suite of elements and sulfate is probably associated with contact-type or, possibly, vein-type mineralization.

\section{GEOPHYSICS}

Aeromagnetic data were collected by fixed-wing aircraft flying at an elevation of $1,000 \mathrm{ft}$ above the average terrain; flightlines were spaced $0.5 \mathrm{mi}$ apart (U.S. Geological Survey, 1979). Analysis and interpretation of the aeromagnetic data have been done by Jachens (1983). The geophysical data provide indirect evidence for evaluating the mineral resource potential of the study area. Such data commonly can be used to extend geologic and geochemical interpretations and to help identify areas that may be favorable for mineralization.

The aeromagnetic survey revealed a pronounced magnetic gradient that separates a large area of poorly magnetic Isabella Granodiorite on the east from more highly magnetic Isabella Granodiorite to the west. This gradient trends generally north-south from Pilot Knob to near White Dome on the west side of the South Fork of the Kern River. From near White Dome the gradient trends northeast through the southeastern part of Rockhouse Basin. The magnetic gradient is defined approximately by the $51,800-n \mathrm{~T}$ (nanotesla) contour (Jachens, 1983). Five of the seven areas with identified geochemical anomalies are alined along this gradient. These five anomalies are, from south to north: The Pilot Knob anomaly (area 3, fig. 2) the South Fork of the Kern River anomaly (area 2), the Black Mountain anomaly (area 5), the Rockhouse Meadow anomaly (area 6), and the anomaly on the east side of Rockhouse Basin (area 7). Association of the geochemical anomalies with the magnetic gradient suggests a correlation between the magnetic gradient and mineralization. Because of this, other areas along the magnetic gradient may also have undiscovered weak mineralization.

The anomaly on the east side of Rockhouse Basin (area 7, fig. 2) straddles part of the contact between the Sacatar Quartz Diorite and the younger Isabella Granodiorite. The geologic contact and its magnetic expression, seen as a steep gradient (Jachens, 1983), extend to the south of the area of the geochemical anomaly; these features may also be the locus of undiscovered weak mineralization.

\section{MINES, PROSPECTS, AND MINERALIZED AREAS}

\section{Domeland Wilderness}

Only 38 mining claims have been located within the Domeland Wilderness. There is no record of any mineral production from any of these claims. 
Assay results of 28 rock, stream-sediment, and placer samples collected by the U.S. Bureau of Mines from within the wilderness indicate no significant mineral resources. The only commodities found in the wilderness are stone (granite), sand, and gravel, which are present in relatively large amounts. Stone occurs primarily in massive exfoliation domes; sand and gravel occur along stream channels.

\section{Woodpecker and Domeland Addition} Roadless Areas

The First record of mining activity in the Woodpecker Roadless Area was in 1901, when gold placers were worked in Rockhouse Basin along the South Fork of the Kern River. Filing of placer claims continued until 1938 and then decreased markedly. Tulare county records indicate that 57 placer-mining claims, one millsite, and 13 lode-mining claims were located within or adjacent to the study area between 1901 and 1968; 34 of the placer claims are along the course of the South Fork of the Kern River in Rockhouse Basin. Old placer workings are still evident in the southern part of Rockhouse Basin (sec. 27, T. 23 S., R. 35 E.), but there is no evidence of present activity.

A total of 12 lode-mining claims have been located within the Woodpecker Roadless Area. The Thistle claim was located in Rockhouse Basin in 1962; the remaining 11 claims were located between 1925 and 1968 in other parts of the Woodpecker Roadless Area. Claim locations were not verified during the field investigation because no claim corners or discovery monuments were found. One pit in the southwest guarter of sec. 34, T. 22 S., R. 35 E., was found and sampled.

Although no records of mineral production could be found for either the Woodpecker or the Domeland Addition Roadless Area, small amounts of placer gold may have been produced from along the South Fork of the Kern River. There are no patented mining claims in the wilderness or roadless areas.

The Woodpecker Roadless Area contains approximately 4.5 million $\mathrm{yd}^{3}$ of indicated low-grade placer gold deposits along the South Fork of the Kern River in Rockhouse Basin (area 1, fig. 2). The gold placers occur in river-terrace deposits and in older Quaternary gravel. At a price of $\$ 500$ per troy ounce and a purity of 83 percent, the gold values from placer samples average $\$ 0.36$ per cubic yard. The highest gold value is $\$ 4.44$ per cubic yard; a few thousand cubic yards may average more than $\$ 1.00$ per cubic yard, but this higher grade gravel occurs only in irregular streaks. The present cost of mining the gravel to recover the placer gold is estimated to be more than $\$ 2$ per cubic yard for a deposit of this size and type. The placer claims are located in the largest outcrop areas of the older Quaternary gravel and in river-terrace deposits to the south. Most sampling was done on claimed ground; however, nearby deposits of older Quaternary gravel that were not sampled are inferred to have similar values.

Gold-bearing gravel on upper Trout Creek in the western part of the Woodpecker Roadless Area (area 1a, fig. 2) yielded gold values as high as $\$ 4.50$ per cubic yard. The average grade, however, is much lower, just as it is in the gold-bearing gravel near the South Fork of the Kern River.

Small irregular tactite bodies (area 9, fig. 2) occur locally at the contact of Kernville carbonate rocks with younger intrusive granitic rocks. Minerals in the tactite include garnet, epidote, calcite, quartz, and diopside. Analyses of samples show low anomalous concentrations of tungsten and vanadium.

The Woodpecker and Domeland Addition Roadless Areas contain large amounts of sand, gravel and stone.

\section{ASSESSMENT OF MINERAL RESOURCE POTENTIAL}

Investigations of the Domeland Wilderness and the contiguous Woodpecker and Domeland Addition Roadless Areas have identified low-grade, presently subeconomic resources of placer gold in the southern part of Rockhouse Basin (area 1, fig. 2). Approximately 4.5 million $\mathrm{yd}^{3}$ of gold- bearing gravel is present along the South Fork of the Kern River in Rockhouse Basin. At $\$ 500$ per troy ounce of gold, these resources are valued at approximately $\$ 0.40$ per cubic yard. Selective mining probably could not produce more than a few tens of thousands of cubic yards of gravel averaging more than $\$ 1$ per cubic yard. The present cost of mining the entire deposit and recovering the gold is estimated by the U.S. Bureau of Mines at more than $\$ 2$ per cubic yard; selective mining of a smaller volume would result in even higher unit costs. Recreational panning, however, could be done at these deposits as well as at those on the upper part of Trout Creek (area 1a, fig. 2). The gold-bearing gravel on the upper part of Trout Creek is of value only for recreational panning, because of the very small volume of gravel (about $1,000 \mathrm{yd}^{3}$ ) and the remoteness of the occurrence.

Data from geochemical and geophysical investigations suggest a low potential for the existence of small mineral deposits in several other areas (fig. 2). A low potential exists for very small deposits of uranium within the Domeland Wilderness in the steep and rugged canyons on the west side of the South Fork of the Kern River. These deposits are likely to occur as secondary uranium mineralization along fractures in the Isabella Granodiorite. On the basis of occurrences and production of uranium in the Kern River uranium area, $17 \mathrm{mi}$ southwest of the wilderness boundary (MacKevett, 1960), any uranium deposits in the wilderness would probably consist of no more than a few tens of tons of ore averaging as much as 0.5 weight percent uranium oxide $\left(\mathrm{U}_{3} \mathrm{O}_{8}\right)$. The small size of potential uranium deposits and the rugged topography of the area will likely preclude development.

At the south end of the Domeland Wilderness, an area near Pilot Knob yielded a geochemical suite of elements that may indicate porphyry molybdenum mineralization. The likelihood of existence of a porphyry molybdenum deposit is low, however, because of the relatively small size of the geochemical anomalies and the absence of corroborating geologic evidence. These data indicate a low potential for molybdenum resources.

Areas of tactite near Trout Creek in the Woodpecker Roadless area (area 9, fig. 2) have a low potential for small deposits of tungsten and other base-metal mineralization.

Several other areas have a low potential for very small deposits of tungsten, copper-lead-zinc, tin, silver, or molybdenum. These areas were identified on the basis of geochemical data, but the small size of the anomalies and the absence of other evidence indicate only a low potential for the occurrence of small undiscovered deposits.

Sand, gravel, and stone are plentiful in the study area, but higher quality material is available closer to existing markets.

The studies revealed no indications of potential for coal, oil and gas, or geothermal resources.

\section{REFERENCES CITED}

Bergquist, J. R., and Nitkiewicz, A. M., 1982, Geologic map of the Domeland Wilderness and contiguous roadless areas, Kern and Tulare Counties, California, with a section on Geochronology, by R.M. Tosdal: U.S. Geological Survey Miscellaneous Field Studies Map MF-1395-A, scale 1:48,000.

Evernden, J. F., and Kistler, R. W., 1970, Chronology of emplacement of Mesozoic batholithic complexes in California and western Nevada: U.S. Geological Survey Professional Paper 623, 42 p.

Jachens, R. C., 1983, Geophysical map and interpretation of the Domeland Wilderness and contiguous roadless areas, Kern and Tulare Counties, California: U.S. Geological Survey Miscellaneous Field Studies Map MF-1395-B, 1 sheet, scale $1: 48,000$.

MacKevett, E. M., Jr., 1931, Geology and ore deposits of the Kern River uranium area, California: U.S. Geological Survey Bulletin 1087-F, p. 169-222.

Miller, W. J., 1931, Geologic sections across the southern Sierra Nevada of California: University of California Publications, Department of Geological Sciences 
Bulletin, v. 20, no. 9, p. 331-360.

Miller, W. J., and Webb, R. W., 1940, Descriptive geology of the Kernville quadrangle, California: California Journal of Mines and Geology, v. 36, no. 4, p. 343368.

Miller, W. R., and McHugh, J. B., 1983, Map showing distribution of anomalous elements in water, Domeland Wilderness and contiguous roadless areas, Kern and Tulare Counties, California: U.S. Geological Survey Miscellaneous Field Studies Map MF-1395-D, scale 1:48,000 [in press].

Miller, W. R., McHugh, J. B., and Motooka, J. M., 1983a, Map showing distribution of anomalous trace elements in the magnetic fraction of heavy-mineral concentrates, Domeland Wilderness and contiguous roadless areas, Kern and Tulare Counties, California: U.S. Geological Survey Miscellaneous Field Studies Map MF-1395-C, scale 1:48,000 in press].

1983b, Map showing distribution of anomalous trace elements in the nonmagnetic fraction of heavymineral concentrates and uranium in the less than $0.180 \mathrm{~mm}$ fraction of selected stream sediments, Domeland Wilderness and contiguous roadless areas, Kern and Tulare Counties, California: U.S. Geological Survey Miscellaneous Field Studies Map MF-1395-E, scale $1: 48,000$ [in press].
Moore, J. G., and Dodge, F. C. W., 1980, Late Cenozoic volcanic rocks of the southern Sierra Nevada, California; I, Geology and petrology: Geological Society of America Bulletin, v. 91, no. 9, p. 515-518.

Motooka, J. M., McHugh, J. B., and Miller, w. R., 1980, Analyses of the heavy-mineral fraction of drainage sediments, Domeland Wilderness and adjacent RARE II study areas, Kern and Tulare Counties, California: U.S. Geological Survey Open-File Report 80-918, 29 p.

Troxel, B. W., and Morton, P. K., 1962, Mines and mineral resources of Kern County, California: California Division of Mines and Geology County Report 1, 370 p.

U.S. Geological Survey, 1979, Aeromagnetic map of the Dome Lands area, California: Open-File Report 79-1234, scale $1: 62,500$. 


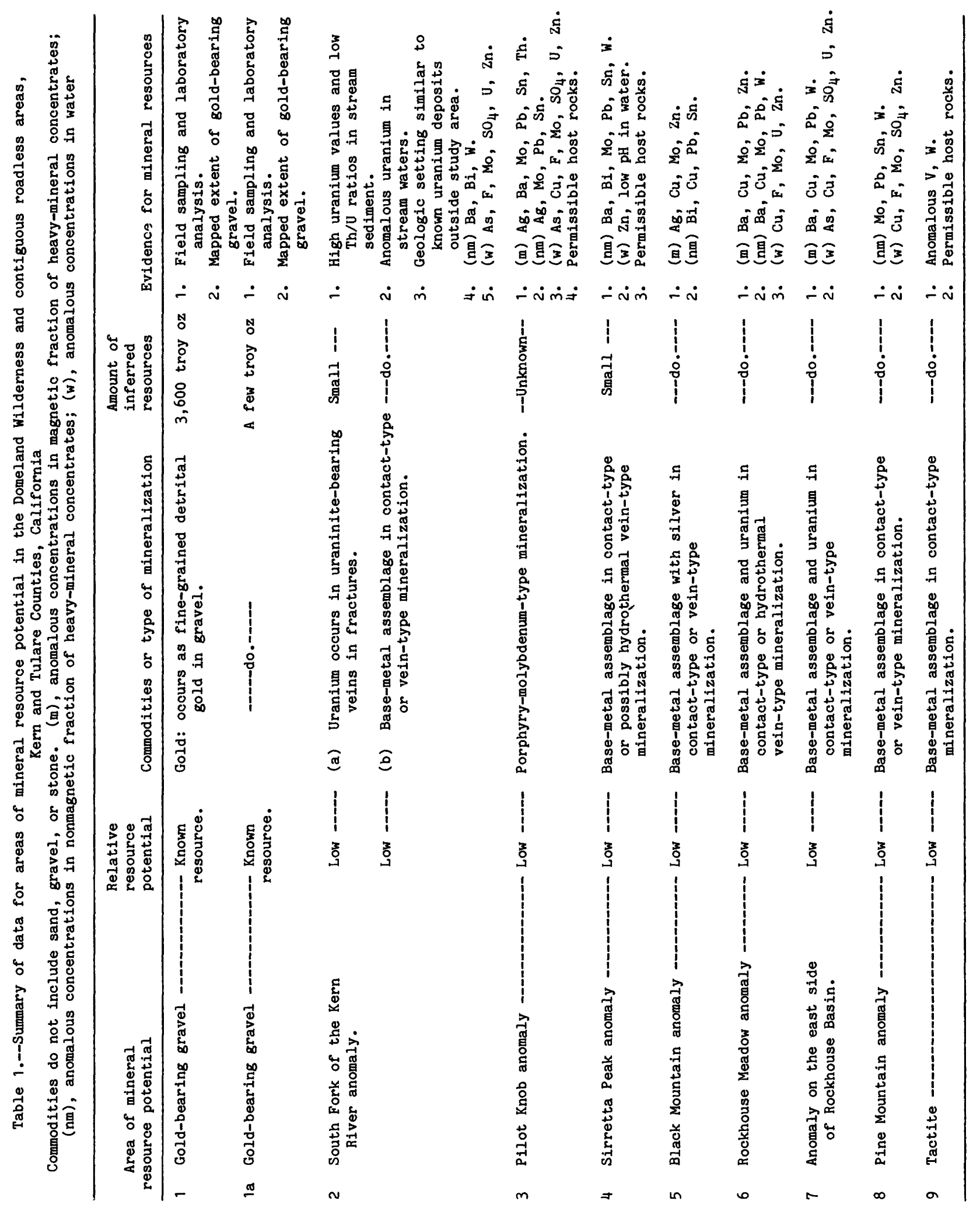




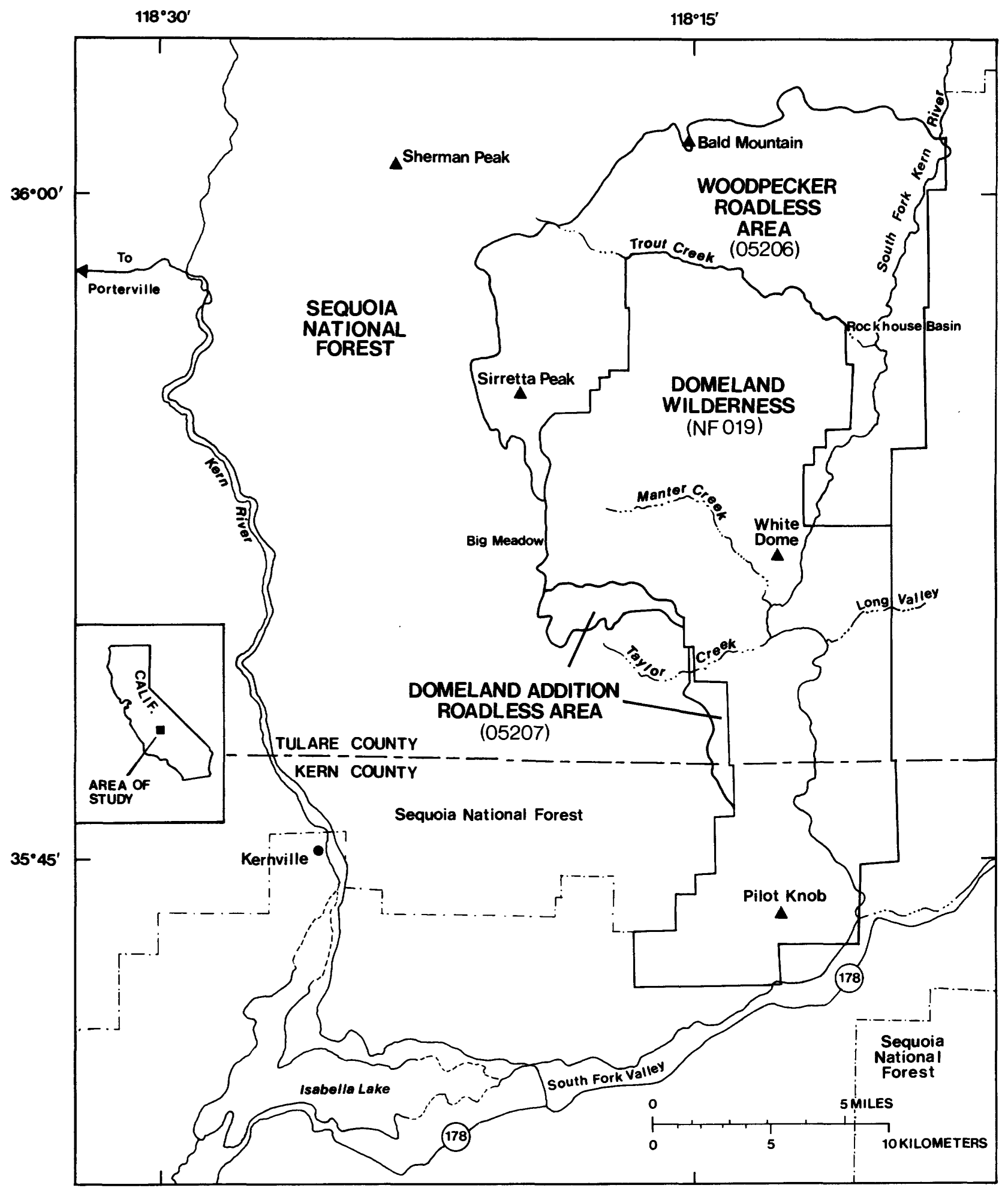

Figure 1.--Index map of study area showing locations of the Domeland Wilderness and and contiguous roadless areas, south-central California. 


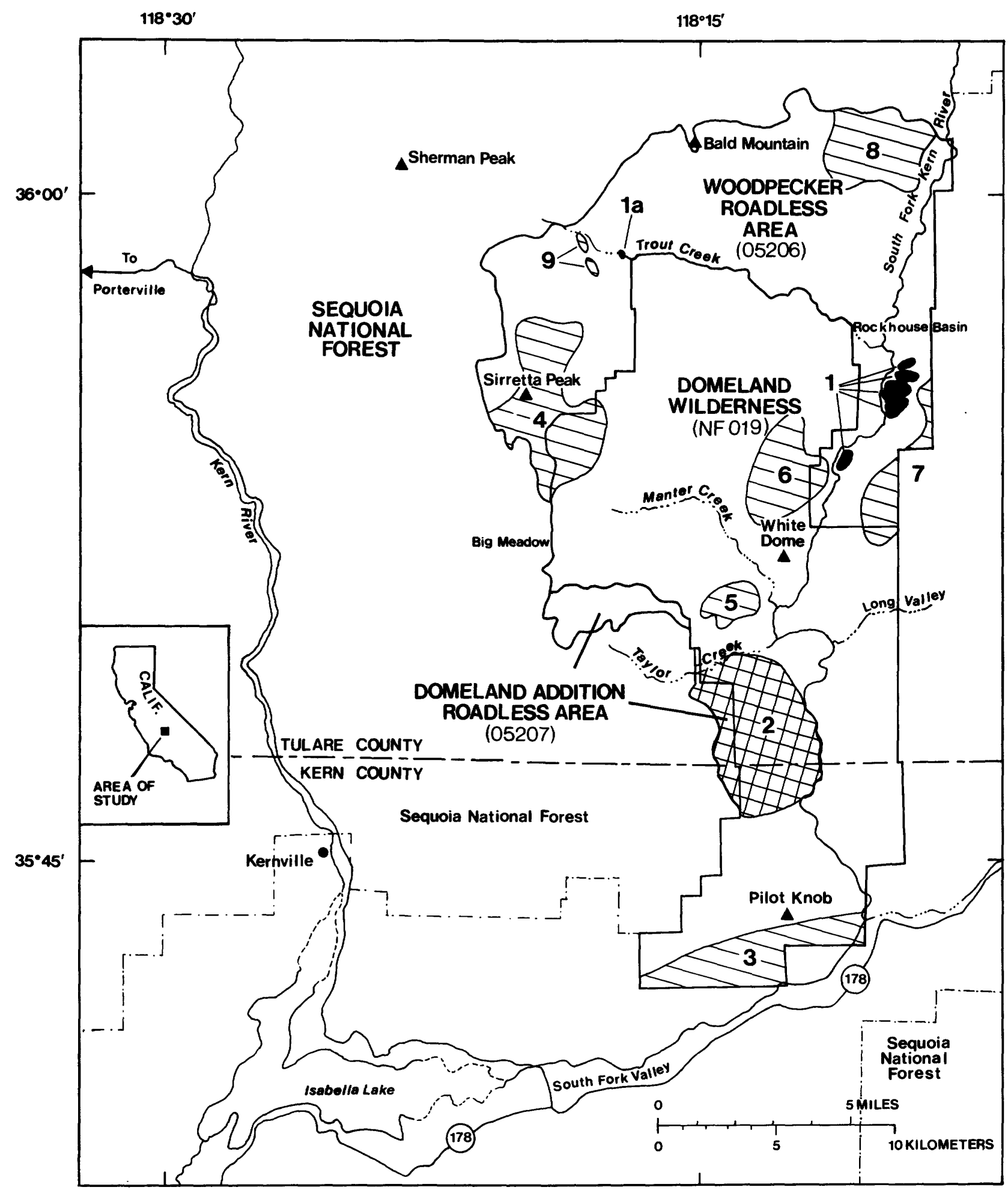

EXPLANATION

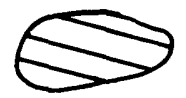

Area with a low potential for small undiscovered mineral deposits of base and (or) precious metals and (or) uranium

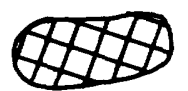

Area with a low potential for small undiscovered deposits of uranium and a low potential for other small undiscovered deposits of base metals

Gold-bearing gravel

Figure 2.-Areas of mineral resource potential in the study area. 